\title{
Studies on LED Wavelength to Enhance Growth and Bio-active Compounds of Carrots
}

\author{
Suna Kang • Min-Jung Kim • Bong Soo Kim - Sunmin Park* \\ 당근의 성장과 생리활성물질 함량을 증진시키는 LED 파장에 관한 연구
}

강선아 · 김민정 · 김봉수 · 박선민*

Received: 5 January 2015 / Accepted: 3 March 2015 / Published Online: 30 June 2015

(C) The Korean Society for Applied Biological Chemistry 2015

\begin{abstract}
Commercial greenhouse plant factories are highly efficient for controlling external factors such as floods, drought, insects, air pollution etc. However, they require substantial startup $\&$ maintenance investments and experimental research to optimize production. These facilities are especially useful for urban farming where high efficiency in small spaces is required. In this study, we investigated whether light emitting diode (LED) lights with mixed dominant wavelengths $(650 \mathrm{~nm}: 550 \mathrm{~nm}: 445 \mathrm{~nm}=8: 1: 1,650 \mathrm{~nm}$ $: 445 \mathrm{~nm}=6: 4)$ can increase the growth rate and bio-active compound content of carrots in comparison to that of fluorescent light (FL). LED with mixed wavelength $(650 \mathrm{~nm}: 550 \mathrm{~nm}: 445$ $\mathrm{nm}=8: 1: 1)$ increased the total weight and root circumference of carrots compared to FL. However, $\beta$-carotene contents were not significant in LED $(650 \mathrm{~nm}: 550 \mathrm{~nm}: 445 \mathrm{~nm}=8: 1: 1)$. However, LED $(650 \mathrm{~nm}: 445 \mathrm{~nm}=6: 4)$ increased the $\beta$-carotene (FL: 7.27,
\end{abstract}

S. Kang and M.-J. Kim contributed equally.

S. Kang $\cdot$ S. Park

Dept. of Food and Nutrition, Division of Biotechnology Industry, Institute of Basic Science, College of Natural Science, Hoseo University, Asan, Republic of Korea

\section{M.-J. Kim}

Food Functional Research Division, Korean Food Research Institutes, Sungnam, Republic of Korea

\section{B. S. Kim}

Dept of R\&D, Korea Parus, Cheoan, Republic of Korea

*Corresponding author (S. Park: smpark@hoseo.edu)

This is an Open Access article distributed under the terms of the Creative Commons Attribution Non-Commercial License (http://creativecommons. org/licenses/by-nc/3.0/) which permits unrestricted non-commercial use, distribution, and reproduction in any medium, provided the original work is properly cited.
LED: $10.48 \mathrm{mg} / \mathrm{g} \beta$-carotene dried weight). These results suggested that using LED light at the ideal wavelength, at the antithesis color of the plant, might enhance plant growth and bio-active compound contents.

Keywords $\beta$-carotene $\cdot$ carrot $\cdot$ growth $\cdot$ light emitting diode $\cdot$ plant factory

\section{서 론}

평균수명이 증가함으로 인해 노인의 인구가 증가하면서 국민들 의 건강(well-being)에 대한 인식도가 날로 증가하고 있는 추세 이다(Jang, 2010). 웰빙은 신체적 정신적으로 건강한 것을 의미 하고 세계보건기구에서 처음 사용하였다. 건강에 관심도가 높아 짐으로 인해 유기농 식품, 친환경 식품, 노화방지 식품, 다이어 트 식품 등 기능성 식품에 대한 소비자의 관심이 높아지고 있다 (Park, 2011; Wang과 Lee, 2012). 이러한 기능성 식품을 생산하 기 위해 다양한 연구가 진행되고 있는데 그 예로 식물공장에서 재배하는 기능성 채소들에 대한 연구가 있다(Jeen과 Son, 2013).

식물공장(Plant factory, vertical farm)은 외부 환경에 영향을 받지 않고 정해진 환경 내에서 질 높은 수확물을 얻기에 적합 한 시설이다. 기상 이변에 영향을 받는 일반 노지나 하우스시 설과 달리 병충해, 이상 기후와 같은 외부의 피해를 막을 수 있 다는 장점을 가지고 있다(Lee, 2010). 전통적인 노지 경작보다 재배 기기가 비싸고 유지비용이 비싸다는 단점이 있으나(Kim, 2010) 이러한 단점을 보완하는 다양한 연구가 이루어지고 있다 (Ijaz 등, 2012; Lee와 Kim, 2013). 식물공장은 기계적으로 빛 과 습도, 온도 등을 조정하여 재배하는데 최근 light emitting diode (LED)를 이용한 식물공장 재배 연구가 늘어가고 있는 추 세이다(Goto, 2012; Lee와 Park, 2014). LED는 가격은 비싸지 
만, 오랫동안 사용할 수 있고 에너지 효율이 높아 형광등이나 백열등에 비해 경제적이라는 장점이 있고, 특정 파장을 조절하 고 혼합하여 사용할 수 있다는 특징이 있어서 형광등을 LED등 으로 바꾸도록 권장하고 있다(Fred 등, 2005).

당근은 뿌리작물로 vitamin $\mathrm{A}$ 의 전구체인 carotenoid를 다량 함유하고 있어 눈 건강에 좋은 채소로 알려져 있다(Karrer 등, 1930). carotenoid는 tetraterpenoids이고 이들은 $400-550 \mathrm{~nm}$ 의 파장을 가진 빛을 흡수한다. 이들은 빛 에너지를 흡수하여 광 합성을 하는데 사용하고 클로로필 II가 빛에 의해서 파괴되는 것을 방지해 주는 역할을 한다. 사람에서는 carotenoid 중에서 $\alpha$-carotene, $\beta$-carotene와 $\beta$-cryptoxanthin이 비타민 $\mathrm{A}$ 의 효과를 나타내며 다른 carotenoid들은 항산화 기능을 한다고 알려져 있 다. 특히 carotinoids 중에서 lutein, astaxanthin와 zeaxanthin는 자외선을 흡수하여 망막을 보호하는 역할을 한다고 알려져 있 다. 특히 밝은 주황빛을 띄는 $\beta$-carotene은 비타민 $\mathrm{A}$ 의 전구체 로 작용할 뿐 아니라(Nishino, 1995) 암의 발생을 방지하는 역 할이 있고(Lee 등, 1985), 산화적 스트레스로 인한 세포의 노화 를 억제하는 역할을 한다고 알려졌다(Terao, 1989; Horton 등, 2001; Rattner와 Nathans, 2006). 당근은 carotenes을 섭취할 수 있는 가장 보편적인 식품이다.

본 연구자 사전연구에 따르면 연구에 사용된 LED 혼합 파 장(red : blue : white $=8: 1: 1)$ 이 적채의 생육과 적채 내 생리활성 물질의 함량을 유의적으로 증진시켰지만, 방울토마토의 성장과 lycopene의 함량에는 영향을 미치지 않았다. 이는 적색의 비율 이 높은 $\mathrm{LED}$ 등이 청색의 비율이 높은 적채의 성장에는 도움 이 되지만 적색이 높은 식물의 성장에는 적합하지 않은 것으로 생각되었다. 이에 당근의 $\beta$-carotene의 함량의 증가에 영향을 미 치는 $\mathrm{LED}$ 의 파장에 관심을 가지게 되었다. 최근에 파장이 다 른 $\mathrm{LED}$ 등으로 당근을 재배하였을 때 당근의 성장과 carotene 함량을 측정한 연구들이 있기는 하지만 다양한 혼합파장에서 연 구한 것은 적었다(Samuolienë와 Duchovskis, 2012; Fu 등, 2013). 본 연구에서는 사전연구를 바탕으로 특정 파장을 조합한 혼합파장을 가진 $\mathrm{LED}$ 를 조사하여 당근의 재배하였을 때 당근 의 성장과 당근의 생리활성물질인 $\alpha$-carotene과 $\beta$-carotene 함량 을 가장 향상시키는 파장을 탐색하는 연구를 하였다.

\section{재료 및 방법}

광원 실험 1. 본 연구에서는 당근의 성장에 효과적인 조도가 $150 \mu \mathrm{mol}^{-1} \mathrm{~m}^{-2} \mathrm{~s}^{-1}$ 로 알려져 있어서 이 조도를 $\mathrm{LED}$ 군과 대조 군에 모두 적용하였다. 대조군의 광원으로 형광등(white oslam super; Oslam, Korea)을 사용하였고, 실험군 광원으로는 LED (Parus, Korea)는 적색 $(650 \mathrm{~nm})$, 백색 $(550 \mathrm{~nm})$ 과 청색 $(445 \mathrm{~nm})$ 파 장을 8:1:1로 혼합한 것을 사용하였다. 대조광인 오슬람 형광등 과 3 색 혼합 $\mathrm{LED}$ 를 각각 평균 $150 \mu \mathrm{mol}^{-1} \mathrm{~m}^{-2} \mathrm{~s}^{-1}$ 로 조사하여 당근의 생육과 생리활성 물질에 미치는 영향을 조사하였다. 이 러한 복합 파장 $\mathrm{LED}$ 를 사용한 것은 적색 파장인 $660-665 \mathrm{~nm}$ 에서는 엽록소 작용이 최대이며, 발아작용과 잎 배포 화아형성 을 극대화하였고, 청색 파장인 430-440 nm에서는 광합성 작용 과 엽록소 작용의 최대를 나타낸다고 보고되어(Massa 등, 2008) 뿌리 생성에 효과적일 것이라고 생각되는 적색 파장을 주파장 으로 하고 광합성에 필요한 청색 파장을 첨가하고 적색 파장과 청색 파장을 연결해주는 board 파장인 백색 파장을 첨가한 $\mathrm{LDE}$
등을 제조하여 사용하였다. Samuolienë와 Duchovskis (2012)에 따르면 백색과 청색파장을 혼합한 $\mathrm{LED}$ 를 조사하여 재배하였을 때 상추에 비타민 $\mathrm{C}$ 와 총 페놀 함량이 증가하였고 적색 파장 도 상추 생산을 증가시켰다(Shin 등, 2012). 또한, 적색과 청색 파장은 $88-238 \mu \mathrm{mol}^{-1} \mathrm{~m}^{-2} \mathrm{~s}^{-1}$ 를 주로 사용하였다(Muneer 등, 2014).

광원 실험 2. 광원실험 1 에서 당근을 재배시 적색 $(650 \mathrm{~nm})$, 백 색 $(550 \mathrm{~nm})$ 과 청색 $(445 \mathrm{~nm})$ 파장을 $8: 1: 1$ 로 혼합한 것이 생리활 성 물질의 생성을 증가시키지 못했다. 이에 당근 내 생리활성 물질을 증가시키는 LED 탐색을 위하여 대조광으로 형광등 (osram $30 \mathrm{~W}$ )을 사용하였고, LED 단파장은 $15 \mathrm{~W}$ 의 445,460 , $470,625,650 \mathrm{~nm}$ 의 파장을 달리하였고, 혼합파장은 적색 $(650$ $\mathrm{nm})$, 청색 $(445 \mathrm{~nm})$ 파장을 $5: 5,6: 4,7: 3,9: 1$ 로 비율을 조정한 LED 사용하였다. 광원 실험 1 에서 백색광은 당근 제조에 큰 영 향을 미치지 않는 것으로 판단되어 적색과 청색 파장의 비율을 조절하여 당근의 성장을 관찰하였다. 이때 조사량은 모두 평균 $150 \mu \mathrm{mol}^{-1} \mathrm{~m}^{-2} \mathrm{~s}^{-1}$ 이었다. 당근의 생리활성 물질에 미치는 LED 의 영향을 조사하였다.

식물 재배 방법. 실내에서 식물의 재배시설을 갖추고 식물재배 공간을 구획하여 대조군으로는 형광등을 공급하였고 실험군으 로 $\mathrm{LED}$ 혼합 광원을 각각 공급하였다. 당근은 농업회사법인 아 시아종묘(주)(Korea)에서 구매하여 재배하였다. 당근의 품종은 국내 재배 품종인 소천 5 촌 종자를 사용하였다. 당근은 재배 조 건 중 온도는 밤낮의 온도 차이 없이 $19 \pm 1^{\circ} \mathrm{C}$ 로 유지시켜 주었 고, 당근은 뿌리 작물이므로 배수 및 성장에 도움을 주기 위해 이랑의 높이를 $20 \mathrm{~cm}$ 로 조성해 주었다. 재식 거리는 $22 \mathrm{~cm}$ 로 하였고, 관수는 1회/2 day로 하였으며 배수를 위해 하단에 구 멍이 뜷린 넓은 화분을 사용하였다. 광량은 8월 31일부터 11월 21 일까지 약 3 개월 동안 조사하였다. 당근을 수확한 후 당근의 총 무게, 뿌리 무게, 뿌리 길이, 뿌리 둘레를 측정하였고 당근 의 색도, 생리활성 물질 함량을 측정하였다.

식물 성장 측정. 당근은 약 3 개월 간 재배 후 수확하였고 당근 의 총 무게와 뿌리무게를 카스전자저울(MW $11-3000 \mathrm{~N}$; 카스전 자저울, Korea)로 측정하였고, 뿌리 길이와 뿌리의 가장 윗부분 의 직경을 버니어캘리퍼스(verniercallipers, (주)메가툴, Japan)를 사용하여 측정하였다. 뿌리의 둘레는 직경으로부터 계산하였다.

색도 측정. 색도의 차이는 당근을 갈아서 여과지로 걸러서 spectrophotometer CM-3500d (Konica Minolta Sensing, INC, $\mathrm{USA}$ 로 조사하였고, L 값(명도; 높을수록 밝은 것), a 값(적색 도; $+\mathrm{a}$ : 적색, $-\mathrm{a}$ : 녹색 $), \mathrm{b}$ 값(황색도; $+\mathrm{b}$ : 황색, $-\mathrm{b}$ : 청색)의 값을 조사하였다.

생리활성 물질 함량 분석. 동결 건조 당근 시료를 취하여 무수 황산나트륨 $\left(\mathrm{Na}_{2} \mathrm{SO}_{4}\right)$ 과 탄산수소나트륨 $\left(\mathrm{NaHCO}_{3}\right)$ 를 넣고 $0.01 \%$ butylated hydroxytoluene (Sigma-Aldrich, USA) 포함한 acetone 을 넣고 혼합하였고, 혼합액은 $5,000 \mathrm{rpm}$ 으로 원심 분리 $\left(4^{\circ} \mathrm{C}\right.$, $10 \mathrm{~min}$ ) 후 상등액을 취하였다. 이러한 추출 과정을 4-5회 반 복하고 원심 분리한 다음 얻어진 상등액을 $0.45 \mu \mathrm{m}$ membrane filter 를 사용하여 여과한 후 High performance liquid chromatograph (HPLC)시료로 사용하였다. HPLC 분석 조건은 Table 1에 주었 다. column은 YMC C30 analytical column $(5.0 \mu \mathrm{m}, 250 \times 4.6$ $\mathrm{mm}$; YMC, Japan)이고 용매의 조성비는 다음과 같았다. 용매 $\mathrm{A}$ 로는 $\mathrm{MeOH}$ : water : trietylamine $(\mathrm{TEA})=90: 10: 0.1$, 용매 $\mathrm{B}$ 는 methyl tert-butyl ether (MTBE) : $\mathrm{MeOH}:$ water : TEA=90:6:4: 0.1 의 비율로 정하였다. 정량을 위한 표준물질은 $\alpha$-carotene과 
Table 1 The conditions of HPLC system to measure the amounts of $\alpha$ and $\beta$-carotene

\begin{tabular}{lc}
\hline & Conditions \\
\hline Column Temperature $\left({ }^{\circ} \mathrm{C}\right)$ & 35 \\
Flow rate $(\mathrm{mL} / \mathrm{min})$ & 1.0 \\
Injection volume $(\mu \mathrm{L})$ & 10 \\
Solvent A : Solvent B $(0-33 \mathrm{~min})$ & $93.5: 6.5$ \\
Solvent B $(34-38 \mathrm{~min})$ & $0: 100$ \\
Detector & $\mathrm{UV} / \mathrm{VIS}$ \\
Detection wavelength $(\mathrm{nm})$ & 203 \\
\hline
\end{tabular}

(A)

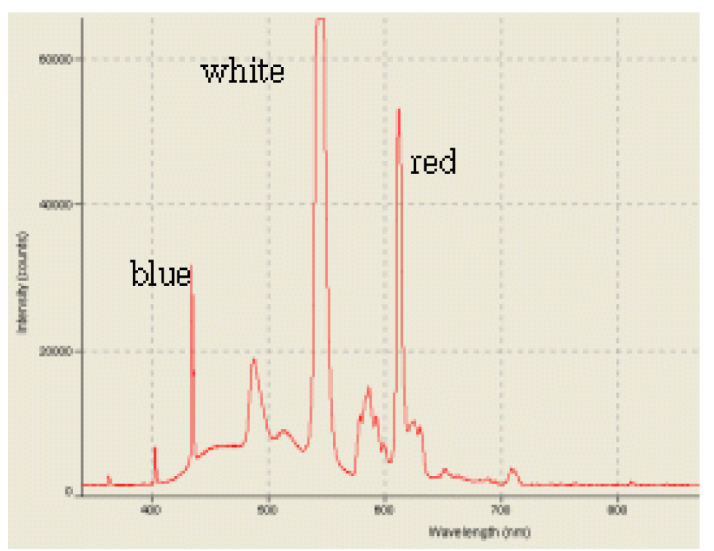

(C)

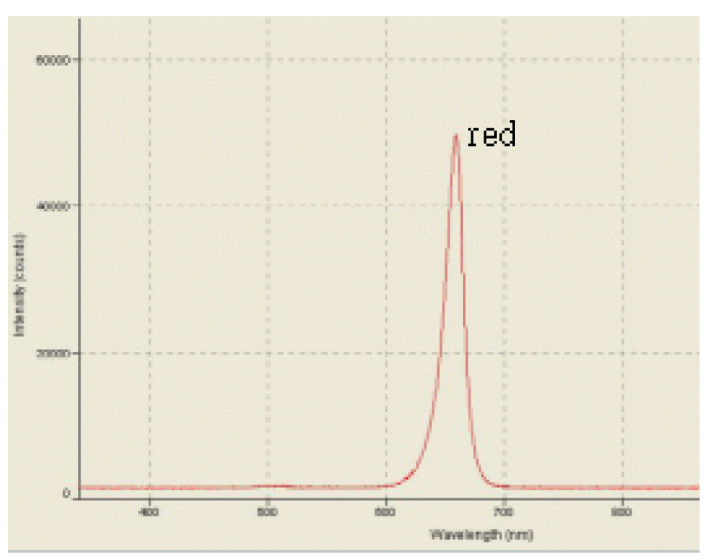

(E)

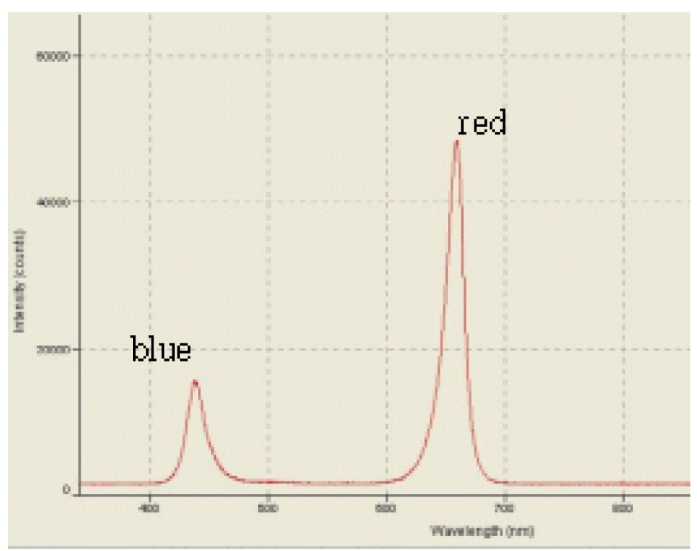

$\beta$-carotene (Sigma, USA)을 외부표준법을 사용하여 표준물질의 함량과 peak의 면적을 비교하여 샘플에 함유된 각 성분의 함량 을 비례식으로 분석하였다.

통계처리. 실험 결과는 통계 처리하여 평균 \pm 표준오차로 측정하 였다. SAS (7.0, SAS, USA)를 이용하여 형광등을 조사한 군 $(\mathrm{FL})$ 과 $\mathrm{LED}$ 를 조사한 군(LED)에 대한 통제적 유의성은 twosampled t-test로 측정하였다. 파장을 달리하여 재배한 군들의 통 계적 유의성은 one-way ANOVA 방법으로 측정하였고 유의적 차이가 있을 때 군들 사이의 통계적 유의성은 Tukey test에 의 해서 검정하였다. 통계적 유의성의 기준은 $p<0.05$ 로 정의하였다.

(B)

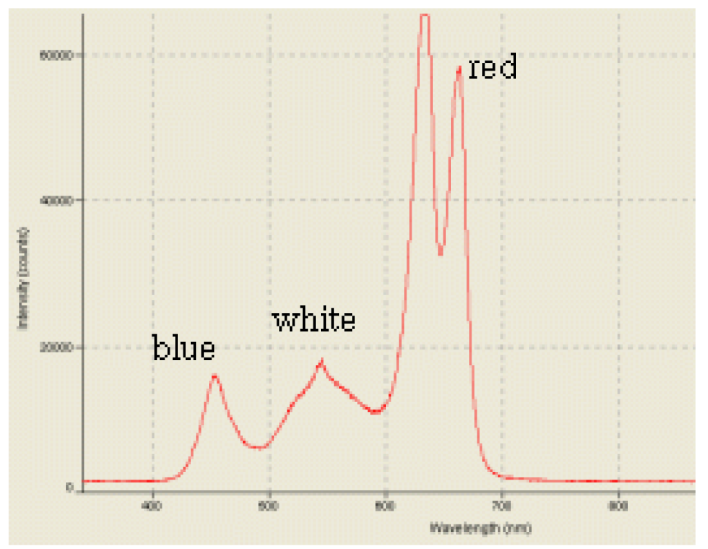

(D)

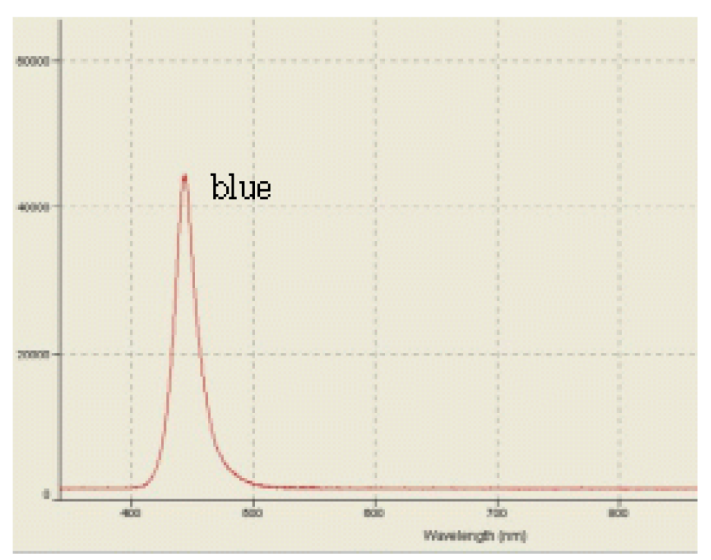

Fig. 1 Spectrometer of fluorescent light and LED.

A. Fluorescent light

B. LED with mixed wavelength (red : blue : white $=8: 1: 1$ )

C. LED with red wavelength

D. LED with blue wavelength

E. LED with mixed wavelength (red : blue $=6: 4$ ) 

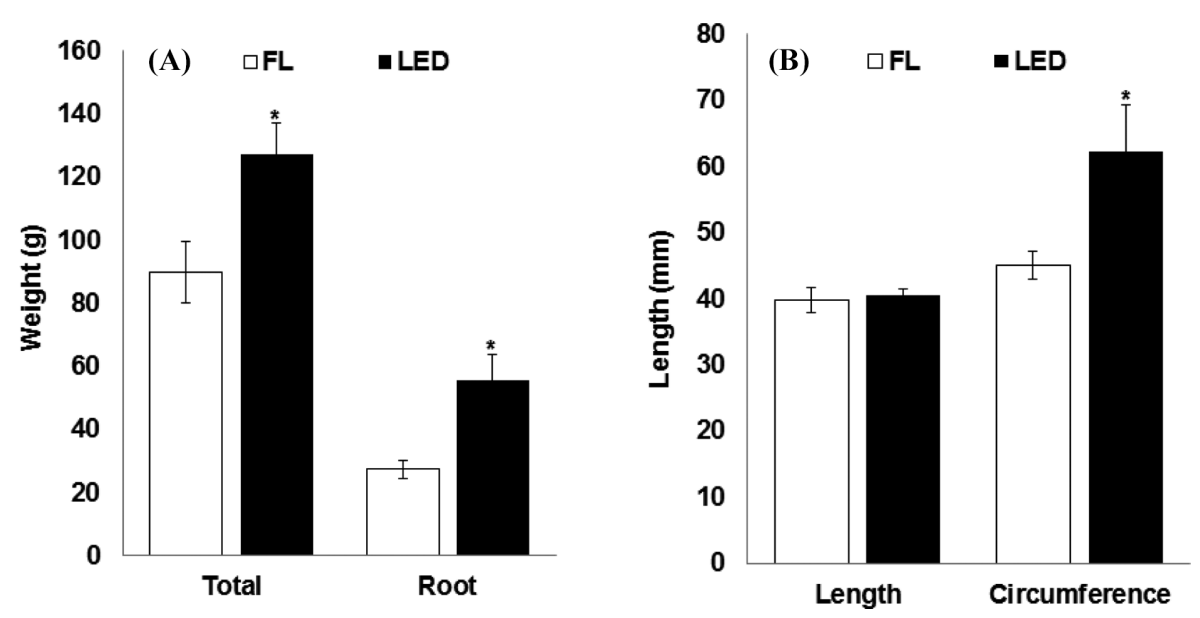

Fig. 2 Growth characteristics of the carrots grown under the fluorescent light (FL) (A) and LED with mixed wavelength (red : blue : white=8:1:1) (B) groups in light experiment 1 . Significantly different from the control group (FL) at $p<0.05$.

\section{결과 및 고찰}

파장 측정. 광원실험 1 에서는 사전 연구에 사용하였던 적색, 청 색, 백색 $(650 \mathrm{~nm}: 550 \mathrm{~nm}: 445 \mathrm{~nm})$ 파장을 $8: 1: 1$ 로 혼합한 $\mathrm{LED}$ 혼합 파장을 사용하였고, 광원실험 2에서는 적색 $(650 \mathrm{~nm})$ 과 청색 $(445 \mathrm{~nm})$ 파장을 $5: 5,6: 4,7: 3,9: 1$ 로 비율을 조정한 $\mathrm{LED}$ 를 조사하여 당근을 재배하였을 때 당근의 성장과 생리활 성물질의 함량을 증진시키는 LED 파장을 탐색하였다. 이때 대 조광으로 형광등을 사용하였다. 실험에 사용한 $\mathrm{LED}$ 의 파장은 Fig. 1에 주었는데 혼합파장 LED (적색파장:청색파장=6:4)에서 적색파장의 최고 파장(peak wavelength)은 $660 \mathrm{~nm}$, 주 파장 (dominant wavelength)은 $650 \mathrm{~nm}$ 이었으며 청색파장의 최고파장 은 $450 \mathrm{~nm}$, 주 파장은 $445 \mathrm{~nm}$ 이었다.

광원 실험 1. 식물 성장 측정. 형광등을 사용한 군의 당근의 총 무게(뿌리+잎)는 $89.8 \mathrm{~g}$ 이었고 LED 혼합 파장(적색:청색:백색= $8: 1: 1, \mathrm{LED}$ 군)을 사용한 군의 총무게는 $218 \mathrm{~g}$ 이었다. 뿌리의 무 게는 형광등 군은 $27.3 \mathrm{~g}, \mathrm{LED}$ 군은 $55.5 \mathrm{~g}$ 이었다(Fig. 2). 총무 게와 뿌리의 무게는 모두 LED 군이 형광등에 비해 통계적으로 유의하게 약 두 배 높은 값을 보였다. 뿌리의 둘레는 두 군 간
Table 2 Comparison of color of carrots grown under the fluorescent light (FL) or LED

\begin{tabular}{cccc}
\hline & $\mathrm{L}$ & $\mathrm{a}$ & $\mathrm{b}$ \\
\hline FL & $31.4 \pm 2.6$ & $17.3 \pm 3.3$ & $32.8 \pm 5.9$ \\
LED & $34.1 \pm 1.8$ & $20.6 \pm 1.3^{*}$ & $36.9 \pm 3.2$ \\
\hline
\end{tabular}

L: Brightness, a: Redness (+red/-green), b: Yellowness (+yellow/-blue) $*$ Significantly different from the control (FL) group at $p<0.05$.

의 차이는 없었으나 $\mathrm{LED}$ 군이 형광등 군에 비해 조금 높은 값 을 나타내었고, 뿌리의 길이는 LED군이 $92.3 \mathrm{~mm}$, 형광등군이 $45.0 \mathrm{~mm}$ 로 $\mathrm{LED}$ 군이 형광등 군에 비해 2 배 이상 유의적으로 높 은 값을 나타내었다. $\mathrm{LED}$ 를 조사한 당근의 무게가 대조군에 비 하여 당근의 성장을 유의적으로 증가시켰다. 본 연구 결과와 유 사하게 Andrei 등(2006)의 연구에 따르면 $\mathrm{LED}$ 를 $526 \mathrm{~nm}$ 로 백 색광에 가깝게 조절하여 $37.2 \mathrm{~W} \mathrm{~m}^{-2}$ 로 당근에 조사하였을 때, $\mathrm{LED}$ 를 조사한 당근의 무게가 대조군인 형광등을 조사한 것보 다 약 두 배 이상 높다고 보고하였다.

광원 실험 1. 색도 및 생리활성물질 측정. 3 개월 동안 형광등,
(A)

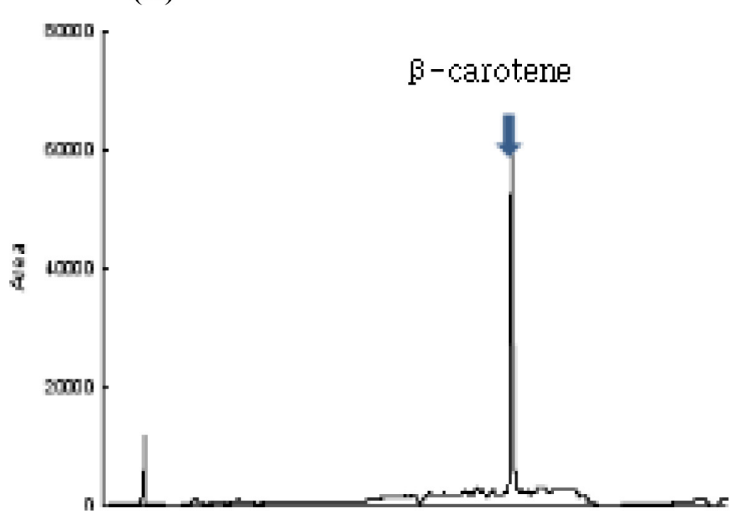

(B)

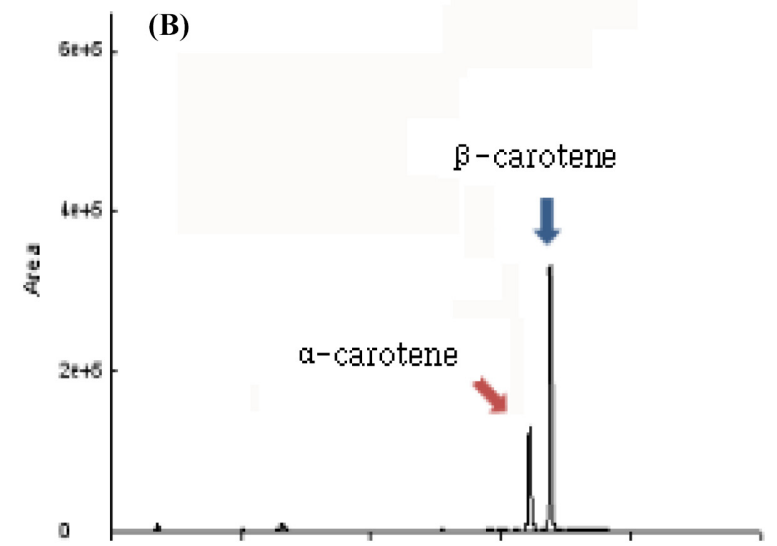

Fig. 3 HPLC chromatograms of acetone extracts of the carrots grown under the fluorescent light (A) and LED with mixed wavelength (red : blue : white=8:1:1) (B) groups in the light experiment 1 . 


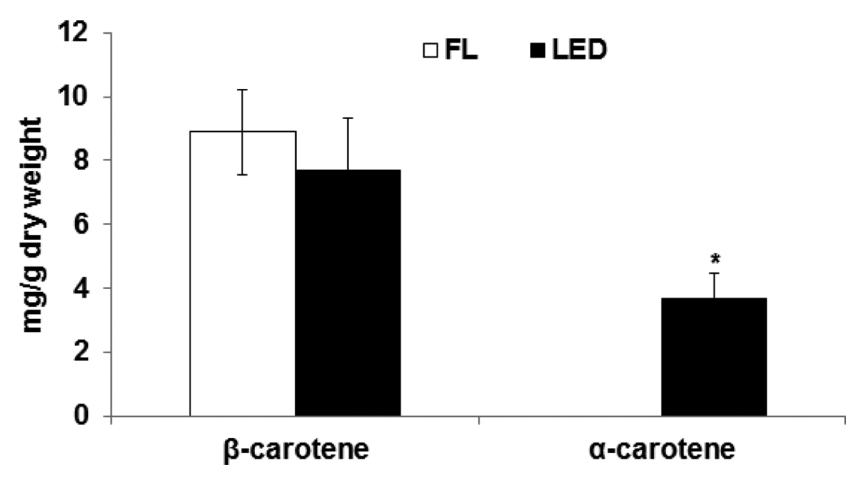

Fig. 4 Contents of $\beta$-carotene and $\alpha$-carotene in the carrots grown under the fluorescent light and LED with mixed wavelength (red:blue : white $=8: 1: 1)$ in the light experiment 1 . ${ }^{*}$ Significantly different from the control group (FL) at $p<0.05$.

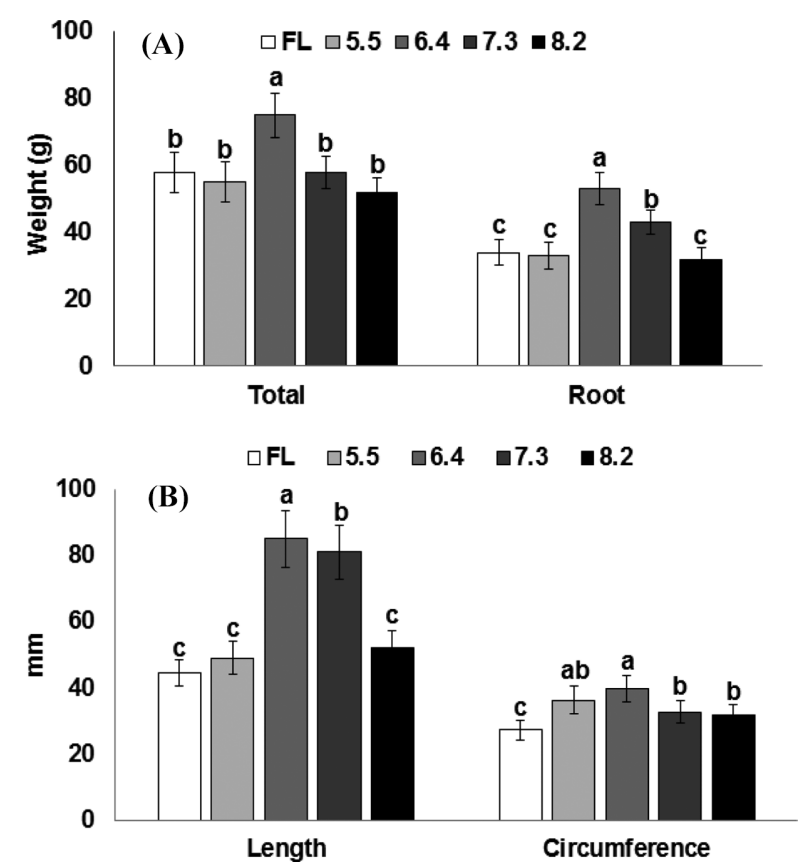

Fig. 5 Growth characteristics of the carrot grown under the fluorescent light (A) and LED with mixed wavelength (red : blue=6:4) (B) groups in the light experiment 2 . $^{\mathrm{a}, \mathrm{b}, \mathrm{c}}$ Different alphabets indicate significant differences.

LED 혼합 파장(적색:청색:백색 $=8: 1: 1)$ 을 조사하여 당근을 재배 한 후 수확하여 색도를 측정하였다(Table 2). LED를 조사하여 키운 당근이 형광등에서 키운 것 보다 적색도와 황색도도 높은 값을 보였고 적색도는 $\mathrm{LED}$ 군에서 형광등군에 비해 통계적으로 유의하게 높았다(Table 2). 결과적으로 LED등에서 키운 것이 형 광등에서 키운 것보다 더 붉고 황색 빛을 나타내었다. 그러나 당근의 $\beta$-carotene 함량 분석 결과 $\mathrm{LED}$ 에서 재배한 당근의 생 리활성물질이 형광등에서 재배한 것 보다 낮게 나왔다(Figs. 3, 4). 반면에 형광등을 조사한 당근과는 달리 $\mathrm{LED}$ 를 조사하여 키 운 당근에는 carotenoid의 하나인 $\alpha$-carotene이 상당량 함유되어 있었다(Fig. 3).

광원 실험 2. 식물 성장 측정. 당근의 총무게(뿌리+잎)는 LED 의 적색과 청색 파장을 혼합한 비에 의해서도 영향을 받아서
Table 3 Comparison of $\beta$-carotene in different condition of the light

\begin{tabular}{cccc}
\hline & & $\begin{array}{c}\beta \text {-carotene } \\
\text { (mg/g dried } \\
\text { weight) }\end{array}$ & $\begin{array}{c}\alpha \text {-carotene } \\
(\mathrm{mg} / \mathrm{g} \text { dried } \\
\text { weight })\end{array}$ \\
\hline & $445 \mathrm{~nm}$ (blue) & $9.83 \pm 0.26^{\mathrm{a}}$ & $3.41 \pm 0.42$ \\
LED single & $460 \mathrm{~nm}$ (blue) & $7.17 \pm 0.39^{\mathrm{b}}$ & $2.32 \pm 0.48$ \\
wave length & $470 \mathrm{~nm}$ (blue) & $7.00 \pm 0.31^{\mathrm{b}}$ & $2.14 \pm 0.31$ \\
& $625 \mathrm{~nm}$ (red) & $5.56 \pm 0.13^{\mathrm{c}}$ & $2.04 \pm 0.39$ \\
& $650 \mathrm{~nm}$ (red) & $7.95 \pm 0.67^{\mathrm{b}}$ & $2.84 \pm 0.46$ \\
\hline & red:blue 5:5 & $6.47 \pm 0.45^{\mathrm{c}}$ & $2.28 \pm 0.44$ \\
LED mixed & red:blue 6:4 & $10.48 \pm 0.28^{\mathrm{a}}$ & $3.84 \pm 0.39$ \\
wave lengths & red:blue 7:3 & $8.90 \pm 0.35^{\mathrm{b}}$ & $3.07 \pm 0.38$ \\
& red:blue 9:1 & $7.18 \pm 0.32^{\mathrm{c}}$ & $2.34 \pm 0.35$ \\
\hline 11 W white-easy on & $6.23 \pm 0.13$ & - \\
20 W white-vungaepyo & $6.02 \pm 0.07$ & - \\
$30 \mathrm{~W}$ white-osram super & $7.27 \pm 0.64^{\mathrm{c}, \mathrm{c}}$ & -
\end{tabular}

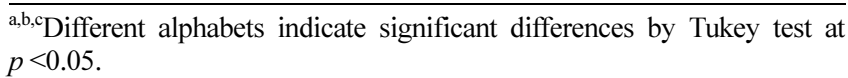

적색과 청색의 비가 6:4일 때 가장 높았지만 다른 군들과 큰 차이는 없었다. 그러나 당근 자체의 무게는 적색과 청색비가 $6: 4$ 과 7:3일 때 모두 형광등에 비해 높았고 $6: 4$ 일 때 가장 무거웠 으며 무게 차이도 컸다(Fig. 5A). 당근 뿌리는 적색과 청색 파 장의 비가 6:4일 때 가장 무거웠던 것은 당근의 길이와 둘레가 모두 길었기 때문이다(Fig. $5 \mathrm{~B}$ ). 특히 적색과 청색비가 7:3인 $\mathrm{LED}$ 는 당근의 길이는 $6: 4$ 의 것과 유사하게 증가시켰으나 당근 의 둘레를 성장시키지 못했고, 5:5는 당근의 둘레는 증가시켰으 나 길이는 증가시키지 못하여서 당근 무게가 6:4의 비를 가진 $\mathrm{LED}$ 에 비해 당근의 무게가 무겁지 않았다. 그러므로 적색과 청 색의 비가 6:4인 $\mathrm{LED}$ 가 가장 뿌리의 성장을 골고루 증가시키 는 것으로 사료되었다. Choi 등(2013)은 적색이나 청색 단 파 장 $\mathrm{LED}$ 보다 적색:청색 $=7: 3$ 혼합파장 $\mathrm{LED}$ 를 딸기에 조사하였 을 때, 과실의 생산량과 생리활성물질인 안토시아닌의 함량을 증가시켰다고 보고하였다. 광원 실험 1,2 와 생리활성 물질 함 량 측정 결과를 참고하면 적색과 청색의 비가 $6: 4$ 인 $\mathrm{LED}$ 를 조 사한 당근이 형광등을 조사한 것 보다 식물의 성장에 효과적이 었고, 생리활성물질 함량에서는 형광등에서는 나타나지 않았던 $\alpha$-carotene이 생성되었다.

광원 실험 2. 생리활성물질 측정. 광원 실험 1 에서 LED 혼합 파 장(적색:청색:백색 $=8: 1: 1)$ 군이 형광등 군에 비해 당근뿌리의 성 장은 향상시켰지만 생리활성물질( $\beta$-carotene)의 함량은 오히려 낮은 경향을 나타내었으므로 당근의 $\beta$-carotene 함량을 증가시 키는 LED 파장을 찾아내기 위해 지속적으로 파장연구를 하였 다. Table 3에 보면 LED 단 파장을 조사하였을 때, 적색인 $650 \mathrm{~nm}$ 와 청색인 $450 \mathrm{~nm}$ 에서 $\beta$-carotene의 함량이 높게 측정되 었고, 적색 $(650 \mathrm{~nm})$ 과 청색 $(445 \mathrm{~nm})$ 혼합 파장을 $6: 4$ 나 7:3으로 조사하였을 때, $\beta$-carotene의 함량이 대조광보다 더 높았다(Table 3, Fig. 6). 본 연구와 유사하게 $\mathrm{Fu}$ 등(2013)의 연구에 따르면 적색과 청색을 $3: 1$ 로 혼합한 $\mathrm{LED}$ 혼합 파장을 $170 \mu \mathrm{E} \mathrm{m}^{-2} \mathrm{~s}^{-1}$ 로 조사한 당근의 carotenoid 함량이 대조광인 형광등에 비해 $285.1 \%$ 높았으며, LED 적색 단파장을 조사하였을 때는 대조광 에 비해 $96.1 \%$ 이었다. 결과적으로 적색과 황색을 $3: 1$ 로 혼합한 $\mathrm{LED}$ 조사가 적색 단파장 $\mathrm{LED}$ 에 비해 3 배 정도 높았다고 보 고하였다. Samuolienë 등(2012)의 연구에 따르면 445, 638, 

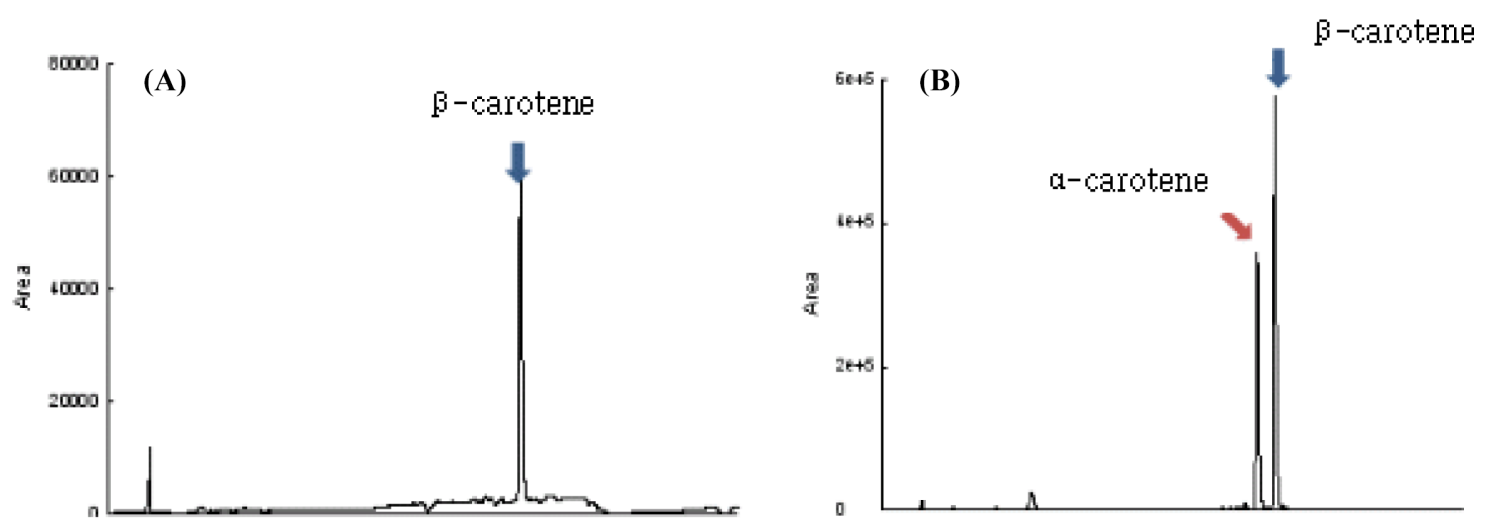

Fig. 6 HPLC chromatograms of the acetone extract of carrots grown under the fluorescent light (A) and LED with mixed wavelength (red : blue=6:4) (B) groups in the light experiment 2.

$731 \mathrm{~nm}$ 혼합파장의 $\mathrm{LED}$ 를 조사하였을 때, 당근의 carotenoid 합 성량을 증가시켰고, 뿌리 내 과당, 자당, 서당의 함량을 증가시 켰다고 보고하였다. 뿐만 아니라 $638 \mathrm{~nm}$ 의 LED가 합성경로에 서 carotenoid antennal complex를 합성을 촉진시킨다고 보고하 였다. 반면에 Lefsrud 등(2008)은 LED 파장이 식물의 biomass 에 미치는 영향을 조사하였는데, $440 \mathrm{~nm}$ 의 청색 파장을 10.6 $\mu \mathrm{mol}^{-1} \mathrm{~m}^{-2} \mathrm{~s}^{-1}$ 로 조사하였을 때, $\beta$-carotene의 량을 증가시켰다 고 보고하여 본 연구 결과와는 다른 연구 결과를 나타내었다. 적색과 청색을 $6: 4$ 로 혼합한 $\mathrm{LED}$ 의 혼합 파장에서 $\beta$-carotene 의 함량이 가장 높게 나왔으므로 이 LED 혼합파장을 조사하여 당근을 생육할 경우 생리활성 물질인 $\beta$-carotene과 $\alpha$-carotene의 함량이 높은 기능성 당근을 수확할 수 있을 것으로 사료된다.

\section{초 록}

$\mathrm{LED}$ 의 적색, 백색, 청색 파장의 비율을 조절한 후 당근에 조사 하여 당근의 생육과 당근의 생리활성 물질인 $\beta$-carotene의 함량 을 증진시키는 파장을 탐색하였다. Light emitting diode (LED) 혼합 파장(적색:청색:백색 $=8: 1: 1)$ 을 조사하였을 때, 당근의 총 무 게와 뿌리의 둘레길이를 증가시켰으나, 뿌리 무게나 길이는 효 과적이지 않았다. $\beta$-carotene의 함량 분석에서도 LED 혼합 파 장은 대조광인 형광등보다 낮은 값을 나타내었다. $\beta$-carotene의 함량을 증진시키는 $\mathrm{LED}$ 의 파장을 연구하기 위해 단색 파장, 적 색과 청색 혼합 파장, 일반 형광등을 당근에 조사하여 $\beta$ carotene의 함량을 분석하였다. $15 \mathrm{~W}$ LED 단색 파장을 조사하 였을 때, $445 \mathrm{~nm}$ 와 $650 \mathrm{~nm}$ 에서 높은 값을 나타내었고 $(445 \mathrm{~nm}$ $=9.8,650 \mathrm{~nm}=9.3 \mathrm{mg} / \mathrm{g}$ dried weight), 적색과 청색 혼합 파장 에서는 $6: 4$ 로 혼합한 혼합 광에서 가장 높은 값을 나타내었다 (10.48 mg/g dried weight). LED 혼합 파장(적색:청색:백색= $8: 1: 1)$ 은 당근의 생육에서만 긍정적인 영향을 미쳤고, $\alpha$-carotene 함량을 증가시키기는 하였으나 $\beta$-carotene의 함량에서는 그 효 과가 미미했다. 추가적으로 당근의 생리활성 물질을 증진시키는 LED 파장을 연구하였을 때, LED 혼합 파장 $(650 \mathrm{~nm}: 445 \mathrm{~nm}$ $=6: 4)$ 이 당근의 성장과 $\alpha$-carotene과 $\beta$-carotene 함랑을 가장 효 과적으로 증가시킨 것으로 나타났다. $\mathrm{LED}$ 청색 파장이 주황빛 을 나타내는 생리활성 물질인 $\beta$-carotene과 $\alpha$-carotene 함량을 증가시키는데 영향을 미치는 것으로 사료된다. 본 실험에서는
사전연구에서 적색 비율이 높았던 LED 혼합 파장(적색:청색: 백색 $=8: 1: 1)$ 이 청색을 나타내는 적채의 anthocyanins의 함량을 높였던 결과와 유사하게 나타났다. LED 혼합 파장(적색:청색: 백색=8:1:1)에서 적색의 비율을 낮추고 청색 파장의 비율을 높 였을 때(적색:청색=6:4), $\beta$-carotene의 함량을 증가시킴을 알 수 있었다. $\mathrm{LED}$ 를 조사하여 작물을 재배할 경우, 재배 작물과 반 대되는 색의 파장의 비율을 높여 $\mathrm{LED}$ 의 파장을 혼합 시켜 조 사하면 작물의 생리활성 물질의 합성을 향상시킬 것으로 기대 한다. $\mathrm{LED}$ 를 조사한 당근의 생육 및 색도, 생리활성 물질 함 량에 대해 연구가 많이 되어있지 않으므로 본 연구가 후에 당 근의 품질을 향상시키는 연구에 도움을 줄 것으로 사료된다.

Keywords 당근 - 발광 다이오드 - 베타-캐로틴 - 성장 - 식물 공장

Acknowledgment 이 논문은 2015년도 산업통상자원부의 '창의산업융합 특 성화 인재양성사업’의 지원을 받아 연구되었음.

\section{References}

Choi HG, Kwon JK, Moon BY, Kang NJ, Park KS, Cho MW et al. (2013) Effect of different light emitting diode (LED) lights on the growth characteristics production of strawberry fruits during cultivation. Kor $J$ Hort Sci Technol 31, 56-64.

Fred S, Thomas G, and Kim JK (2005) Light emitting diode. Kirk-Othmer Encyclopedia Chem Tech 2, 1-33.

Fu W, Guðmundsson Ó, Paglia G, Herjólfsson G, Andrésson Ó.S, Palsson BØ et al. (2013) Enhancement of carotenoid biosynthesis in the green microalga Dunaliellasalina with light-emitting diodes and adaptive laboratory evolution. Applied Microbiology Biotechnol 97, 2395-403.

Goto E (2012) Plant production in a closed plant factory with artificial lighting. In: VII International Symposium on Light in Horticultural Systems 956, 37-49.

Horton JW, White DJ, Maass DL, Hybki DP, Haudek S, and Giroir B (2001) Antioxidant Vitamin Therapy Alters Burn Trauma-Mediated Cardiac NF-[kappa] B Activation and Cardiomyocyte Cytokine Secretion. J Trauma-Injury, Infection, \& Critical Care 50, 397-408.

Ijaz F, Siddiqui A, Im K, and Lee C (2012) Remote management and control system for LED based plant factory using ZigBee and Internet. In Advanced Communication Technol (ICACT), 2012 14th International Conference on, 942-6. IEEE, USA.

Jang YJ (2010) Food-related lifestyle segments of older consumers in Seoul 
and its characteristics. J Korean Soc Food Sci Nutr 39, 146-53.

Jeen JH and Son JE (2013) Modeling of canopy light interception of lettuce in LED plant factory. Korean Soc Agricul Machinery 18, 349-50.

Karrer P, Helfenstein A, Wehrli H, and Wettstein A (1930) Pflanzenfarbstoffe XXV. Über die Konstitution des Lycopins und Carotins. Helvetica Chimica Acta 13, 1084-99.

Kim HR and You YH (2013) Effects of red, blue, white, and far-red LED slurce on growth responses of Wasabia japonica seedlings in plant factory. Kor J Hort Sci Technol 31, 415-22.

Kim JW (2010) Trend and direction for plant factory system. J Plant Biotechnol 37, 442-55

Lee KY, Lee YC, Park YS, Yoon KH, and Kim BS (1985) A study of relation between dietary vitamin A levels and cancer risk in Korea. Korean $J$ Nutr 18, 301-11.

Lee SW (2010) Plant cultivation using plant factory and LED artificial light. Optical Sci Technol 14, 12-9.

Lee SW and Park SK (2014) LED array design for optimal combination of plant grown. J Plant Biotechnol 41, 123-6.

Lee WS and Kim SG (2013) Analysis of photosynthetic photon flux by prototype of rotational lighting system for plant factory. $J$ Korea Academia-Industrial Cooperation Soc 14, 529-34.

Lefsrud MG, Kopsell DA, and Sams CE (2008) Irradiance from distinct wavelength light-emitting diodes affect secondary metabolites in kale. HortSci 43, 2243-4.
Massa GD, Kim HH, Wheeler RM, and Mitchell CA (2008) Plant productivity in response to LED lighting. HortSci 43, 1951-6.

Muneer S, Kim EJ, Park JS, and Lee JH (2014) Influence of green, red and blue light emitting diodes on multiprotein complex proteins and photosynthetic activity under different light intensities in lettuce leaves (Lactuca sativa L.). Int J Mol Sci 17, 4657-70.

Nishino H (1995) Cancer chemoprevention by natural carotenoids and their related compounds. J Cell Biochem Suppl 22, 231-5.

Park KH (2011) The relationships between well-being lifestyle, well-being attitude, life satisfaction, and demographic characteristics. Family Environ Res 49, 39-49.

Rattner A and Nathans J (2006) Macular degeneration: recent advances and therapeutic opportunities. Nat Rev Neurosci 7, 860-72.

Samuolienë G and Duchovskis P (2012) Interaction between flowering initiation and photosynthesis. Applied Photosynthesis 121, 121-40.

Shin YS, Lee MJ, Lee ES, Ahn JH, Lim JH, Kim HJ et al. (2012) Effect of LEDs (light emitting diodes) irradiation on growth and mineral absorption of lettuce (Lactuca sativa L. 'Lollo Rosa'). J Kor Bio-Environ control 21, 180-5.

Terao J (1989) Antioxidant activity of $\beta$-carotene-related carotenoids in solution. Lipids 24, 659-61.

Wang H and Lee SL (2012) Well-being orientation, consumer needs for lunch, and lunch behaviors. Life Sci 15, 99-119. 